\title{
Differentiation of Two Genetically Specific Types of Depression by the Response to Antidepressant Drugs
}

\author{
C. M. B. PARE and J. W. MACK \\ From St Bartholomew's Hospital, London
}

The inability to separate depressive illnesses into distinct homogeneous entities seriously hampers research into their aetiology and treatment. This enquiry is aimed at investigating whether depressive illnesses can be classified pharmacogenetically.

A depressed patient may respond dramatically to one antidepressant yet be completely resistant to another. However, the patient's response tends to be similar to drugs from the same pharmacological group of antidepressants, in contrast to their response to drugs from a different group. Thus a survey of patients in whom the response to antidepressants were known because of their inclusion in 'double-blind' trials revealed 16 and 12 who had received two different drugs of the monoamine oxidase inhibitor or tricyclic group respectively (Table I). It is clear that patients tend to respond

TABLE I

SIMILARITY IN RESPONSES OF A DEPRESSED ATIENT TO TWO DIFFERENT DRUGS BELONGING TO THE SAME PHARMACOLOGICAL GROUP

\begin{tabular}{|c|c|c|c|}
\hline & \multicolumn{2}{|c|}{ Second Drug } & \multirow[b]{2}{*}{ Total } \\
\hline & Improvement & No Improvement & \\
\hline \multicolumn{2}{|c|}{ Response to 2 different $M A O$ inhibitors* } & & \\
\hline $\begin{array}{l}\text { First drug: } \\
\text { Improvement } \\
\text { No improvement } \\
\text { Total }\end{array}$ & $\begin{array}{l}9 \\
0 \\
9\end{array}$ & $\begin{array}{l}0 \\
7 \\
7\end{array}$ & $\begin{array}{r}9 \\
7 \\
16\end{array}$ \\
\hline \multicolumn{3}{|c|}{ Response to 2 different drugs of the tricylic groupt } & \\
\hline $\begin{array}{l}\text { Improvement } \\
\text { No improvement } \\
\text { Total }\end{array}$ & $\begin{array}{l}7 \\
0 \\
7\end{array}$ & $\begin{array}{l}1 \\
4 \\
5\end{array}$ & $\begin{array}{r}8 \\
4 \\
12\end{array}$ \\
\hline
\end{tabular}

* $P=0.000087$. $+P=0.012$.

to drugs from the same group in a similar way and in contrast to their response to two antidepressants from different groups (Table II) (Pare, 1965). Similar conclusions were reached by Dally (1960) and Dally and Rohde (1961).

Received 23 October 1970
TABLE II

INCONSISTENCY OF RESPONSES OF DEPRESSED PATIENTS TO TWO DRUGS FROM DIFFERENT PHARMACOLOGICAL GROUPS

\begin{tabular}{l|c|c|c}
\hline & \multicolumn{3}{|c|}{ Tricylic Group } \\
\cline { 2 - 4 } & Improvement & No Improvement & Total \\
\hline MAO inhibitors: & & 15 & 20 \\
Improvement \\
$\begin{array}{c}\text { No improvement } \\
\text { Total }\end{array}$ & 15 & 30 & 45 \\
\hline
\end{tabular}

It is suggested that a patient's response to antidepressant drugs depends to a considerable extent on the fundamental biochemical abnormality of his illness, and that this in turn depends on the genetic type of his depression, one type responding to members of the tricylic group of drugs, another to the monoamine oxidase inhibitors. If this is so, one could predict that first-degree relatives who became depressed should respond to antidepressants in a similar way to the proband. Secondly, these correlations should be quite different from the response of proband and first degree relative to antidepressants from different groups. Evidence supporting the first part of this prediction has been published by Pare, Rees, and Sainsbury (1962) and by Angst (1961-64).

In the present paper we have re-examined our original material (Pare et al, 1962) to test the second part of the hypothesis and retested the whole hypothesis in a new series of subjects.

\section{Old Material}

Method. Pare et al (1962) studied 170 depressed patients whose response to antidepressant drugs was known because of their participation in controlled trials. Enquiries were made for any first-degree relatives of these patients who might have had a depressive illness and been treated at hospital with antidepressant drugs. The hospital records of these relatives were studied by 306 
TABLE III

FAMILY CORRELATIONS OF RESPONSE TO ANTIDEPRESSANTS

(From Pare et al, 1962)

\begin{tabular}{|c|c|c|c|c|c|}
\hline Case No. & Drug & Response & Relation & Drug & Response \\
\hline 3 & Phenelzine & \pm & Sister & Phenoxypropazine & + \\
\hline $\begin{array}{l}13 \\
57\end{array}$ & $\begin{array}{l}\text { Pmipramine } \\
\text { Phenelzine } \\
\text { Amitriptyline } \\
\text { Phenelzine }\end{array}$ & $\begin{array}{l}+ \\
+ \\
+\end{array}$ & $\begin{array}{l}\text { Sister } \\
\text { Father }\end{array}$ & $\begin{array}{l}\text { 'Parstelin' } \\
\text { Imipramine }\end{array}$ & $\begin{array}{l}+ \\
+\end{array}$ \\
\hline 236 & $\begin{array}{l}\text { Isocarboxazid } \\
\text { Imipramine }\end{array}$ & $\bar{z}$ & $\begin{array}{l}\text { Father } \\
\text { Brother }\end{array}$ & $\begin{array}{l}\text { Phenelzine } \\
\text { Amitriptyline } \\
\text { Imipramine } \\
\text { Nialamide }\end{array}$ & $\begin{array}{l}- \\
- \\
-\end{array}$ \\
\hline 243 & $\begin{array}{l}\text { Imipramine } \\
\text { Isocarboxazid }\end{array}$ & $\overline{-}$ & Sister & Imipramine & - \\
\hline 250 & Isocarboxazid & + & Sister & Tranylcypromine & $\overline{+}$ \\
\hline 300 & $\begin{array}{l}\text { Imipramine } \\
\text { Imipramine }\end{array}$ & $\overline{+}$ & Sister & $\begin{array}{l}\text { Imipramine } \\
\text { Imipramine }\end{array}$ & $\bar{t}$ \\
\hline
\end{tabular}

TABLE IV

RESPONSE OF PATIENTS AND FIRST-DEGREE RELATIVES TO ANTIDEPRESSANT DRUGS FROM THE SAME AND DIFFERENT PHARMACOLOGICAL GROUPS (From Pare et al, 1962)

\begin{tabular}{|c|c|c|c|c|}
\hline & \multicolumn{4}{|c|}{ Relatives } \\
\hline & \multicolumn{2}{|c|}{ MAO Inhibitors } & \multicolumn{2}{|c|}{ Tricyclic } \\
\hline & Improvement & No Improvement & Improvement & No Improvement \\
\hline $\begin{array}{l}\text { Probands } \\
\text { MAO Inhibitors: } \\
\text { Improvement } \\
\text { No improvement }\end{array}$ & 3 & 3 & 1 & $\begin{array}{l}1 \\
3\end{array}$ \\
\hline $\begin{array}{l}\text { Tricyclic: } \\
\text { Improvement } \\
\text { No improvement }\end{array}$ & 2 & 3 & 2 & 4 \\
\hline
\end{tabular}

TABLE V

FAMILY CORRELATIONS OF RESPONSE TO ANTIDEPRESSANTS (From Angst, 1964)

\begin{tabular}{|c|c|c|c|c|c|c|c|c|c|}
\hline & \multirow{2}{*}{\multicolumn{3}{|c|}{$\begin{array}{l}\begin{array}{l}\text { Results of } \\
\text { Treatment }\end{array} \\
\text { Individuals }\end{array}$}} & \multicolumn{5}{|c|}{ Results of Treatment } & \multirow{3}{*}{$\mathbf{P}$} \\
\hline & & & & \multicolumn{4}{|c|}{ In Pairs } & \multirow{2}{*}{$\begin{array}{l}\text { Total } \\
\text { No. of } \\
\text { Pairs }\end{array}$} & \\
\hline & + & 0 & Total & ++ & +0 & $0+$ & 00 & & \\
\hline $\begin{array}{l}\text { Endogenous depression } \\
\text { Parents and children } \\
\text { Sibs } \\
\text { Distant relations } \\
\text { Total } \\
\end{array}$ & $\begin{array}{r}38 \\
30 \\
9 \\
77 \\
\end{array}$ & $\begin{array}{r}1 \\
10 \\
3 \\
14\end{array}$ & $\begin{array}{l}39 \\
40 \\
12 \\
91\end{array}$ & $\begin{array}{r}20 \\
14 \\
3 \\
37\end{array}$ & $\begin{array}{l}1 \\
1 \\
1 \\
3\end{array}$ & $\begin{array}{l}0 \\
1 \\
1 \\
2\end{array}$ & $\begin{array}{l}0 \\
4 \\
1 \\
5\end{array}$ & $\begin{array}{r}21 \\
20 \\
6 \\
47\end{array}$ & 0.0007 \\
\hline $\begin{array}{l}\text { Detression of mixed aetiology } \\
\text { Schizo-affective }\end{array}$ & 18 & 12 & 30 & 5 & 4 & 4 & 2 & 15 & \\
\hline
\end{tabular}

$+=$ Responders; $0=$ Non-responders. 
TABLE VI

FAMILY CORRELATIONS OF RESPONSE TO ANTIDEPRESSANTS (Present series)

\begin{tabular}{|c|c|c|c|c|c|}
\hline Proband & Drug & Response & Relative & Drug & Response \\
\hline 1 & Imipramine & + & Brother & $\begin{array}{l}\text { Imipramine } \\
\text { Parstelin }\end{array}$ & + \\
\hline 6 & $\begin{array}{l}\text { Imipramine } \\
\text { Parstelin }\end{array}$ & + & Mother & $\begin{array}{l}\text { Nortriptyline } \\
\text { Parstelin }\end{array}$ & \pm \\
\hline 9 & Parstelin & + & Sister & Imipramine & - \\
\hline $\begin{array}{l}11 \\
17\end{array}$ & $\begin{array}{l}\text { Imipramine } \\
\text { Imipramine }\end{array}$ & $\begin{array}{l}+ \\
-\end{array}$ & $\begin{array}{l}\text { Daughter } \\
\text { Daughter }\end{array}$ & $\begin{array}{l}\text { Amitriptyline } \\
\text { Imipramine }\end{array}$ & $\begin{array}{l}+ \\
+\end{array}$ \\
\hline 22 & $\begin{array}{l}\text { Imipramine } \\
\text { Parstelin }\end{array}$ & $\begin{array}{l}+ \\
+\end{array}$ & $\begin{array}{l}\text { Sister } \\
\text { Mother }\end{array}$ & $\begin{array}{l}\text { Phenelzine } \\
\text { Phenelzine } \\
\text { Parstelin } \\
\text { Iminramine }\end{array}$ & $\begin{array}{l}- \\
\overline{-}\end{array}$ \\
\hline $\begin{array}{l}37 \\
40 \\
54 \\
61 \\
63 \\
72\end{array}$ & $\begin{array}{l}\text { Amitriptyline } \\
\text { Imipramine } \\
\text { Trimipramine } \\
\text { Imipramine } \\
\text { Imipramine } \\
\text { Imipramine }\end{array}$ & $\begin{array}{l}+ \\
+ \\
+ \\
+ \\
+ \\
+\end{array}$ & $\begin{array}{l}\text { Sister } \\
\text { Sister } \\
\text { Sister } \\
\text { Daughter } \\
\text { Sister } \\
\text { Sister }\end{array}$ & $\begin{array}{l}\text { Amitriptyline } \\
\text { Imipramine } \\
\text { Imipramine } \\
\text { Desipramine } \\
\text { Amitriptyline } \\
\text { Phenelzine }\end{array}$ & $\begin{array}{l}+ \\
+ \\
+ \\
+ \\
+\end{array}$ \\
\hline
\end{tabular}

TABLE VII

RESPONSE OF PATIENTS AND FIRST-DEGREE RELATIVES TO ANTIDEPRESSANT DRUGS FROM THE SAME AND DIFFERENT PHARMACOLOGICAL GROUPS

(Present series)

\begin{tabular}{l|c|c|c|c}
\hline & \multicolumn{3}{|c|}{ Relatives } \\
\hline & \multicolumn{2}{|c|}{ MAO Inhibitors } & & Tricyclic \\
\hline Improvement & No Improvement & Improvement & No Improvement \\
\hline $\begin{array}{l}\text { MAO Inhibitors } \\
\text { No improvement }\end{array}$ & 1 & & & 2 \\
\hline $\begin{array}{l}\text { Tricyclic } \\
\text { Improvement } \\
\text { No improvement }\end{array}$ & & 1 & 1 & 1 \\
\hline
\end{tabular}

\section{Present Series}

one of the authors who was unaware of the probands' response to treatment. He was able to find 8 relatives (of 7 probands) in whom the diagnosis was reasonably certain. These relatives had received an antidepressant drug in adequate doses and for an adequate period of time, and the notes were sufficient to make an assessment of the response to the drug.

Results. There were 12 correlations between proband and relative where each had received the same group of drug and in every case the response was similar $(P<0.001)$ (Table III). Re-examination of the material revealed 10 correlations where the proband and first-degree relative received antidepressants from different groups when there was no similarity in response (Table IV).

Angst's material, using only imipramine, is summarized in Table V (Angst, 1964). Forty-seven pairs of depressed probands and relatives tended to have a similar response to imipramine $(P<0.0007)$ compared to proband/relative pairs with depressive symptoms of mixed aetiology.
Method. Using a similar method to that of Pare et al (1962), 515 probands were contacted. Thirteen of these had first-degree relatives in whom a blind assessment of medical records and personal interview enabled us to make a confident diagnosis of depression and a definite assessment of their response to an antidepressant drug (Table VI).

Results. Ten patient/relative pairs, each of whom had received a drug from the same group of antidepressants, resulted in 12 correlations. Of these 10 were concordant, but because of the high success rate of the tricyclic antidepressants this did not reach a significance level of 5\%. The similarity between the response of proband and first degree relative when they received an antidepressant from the same group was, however, in marked contrast to their differing responses when drugs of different groups were used (Table VII). 


\section{Discussion}

The results support the suggestion that the response to a particular group of antidepressants is at least in part genetically determined. Investigations with the monoamine oxidase inhibitor, nialamide, did not point to a variability in absorption, distribution, metabolism, or excretion of the drug as being different in patients who subsequently responded or did not respond to the drug (Pare and Jenner, 1966). Studies of amine concentrations in the human brain following administration of monoamine oxidase inhibitors show a wide scatter, some patients only showing a small increase in amine concentrations. However, there is no evidence of a bimodal distribution suggesting two populations, one of whom might respond clinically and one who would not (Jones et al, 1971). It is suggested that the drug response depends in part on the biochemical type of depression, that there are at least two types, one responding to the monoamine oxidase inhibitors, another to the tricyclic group of antidepressants, and that the biochemical abnormalities in these two types of depression are genetically determined.

From a practical point of view this does not necessarily mean that these types cannot be distinguished clinically. The impression (Sargant, 1961) that 'endogenous' depressions are more likely to benefit from the tricylic group of drugs, and the 'reactive' type from monoamine oxidase inhibitors, if correct, could be explained by a varying degree of genetic predisposition. For instance, if the genetic predisposition of the 'tricyclic' group of depression is strong, then a depressive illness would become manifest under mild stress and the depression would be classified as endogenous by the clinician. On the other hand, if there was only a weak predisposition to depression in the 'amine oxidase inhibitor' group, then a large exogenous factor might be necessary to precipitate an overt illness, and this would tend to be classified as reactive.
But other inherited or acquired personality factors would be expected to modify any such genetic predisposition and to obscure any simple differentiation in terms of reactive or endogenous depression, as set out above.

\section{Summary}

The response to a particular antidepressant drug in a first-degree relative who becomes depressed, is similar to that of the depressed proband. However there is no similarity of response when antidepressants of different groups are used. The results support the suggestion that there is more than one biochemical abnormality which may result in depressive illnesses, and that these are genetically specific.

We would like to thank the Governors of St. Bartholomew's Hospital and the Medical Research Council for grants to C.M.B.P. and J.W.M. respectively.

\section{REFERBNCES}

Angst, J. (1961). A clinical analysis of the effects of tofranil in depression. Longitudinal and follow-up studies. Treatment of blood relations. Psychopharmacologia, 2, 381-407.

Angst, J. (1964). Antidepressiver Effekt und genetische Faktoren. Arzneimittel-Forschung, 14, Suppl., 496-500.

Dally, P. J. (1960). Symposium on Depression, Royal College of Surgeons, London.

Dally, P. J. and Rohde, P. (1961). Comparison of antidepressant drugs in depressive illnesses. Lancer, 1, 18-20.

Jones, B. B., Nicholson, W. J., Pare, C. M. B., Price, K., and Stacey, R. S. (1971). The effect of monoamine oxidase inhibitors on the concentrations of 5-hydroxy tryptamine, noradrenaline, and dopamine in brain stem, hypothalamus, and caudate nucleus in the human brain. (In press.)

Pare, C. M. B., Rees, L., and Sainsbury, M. J. (1962). Differentiation of two genetically specific types of depression by the response to anti-depressants. Lancet, 2, 1340-1343.

Pare, C. M. B. (1965). Some clinical aspects of antidepressant drugs. In The Scientific Basis of Drug Therapy in Psychiatry, edited by J. Marks and C. M. B. Pare, pp. 103-113. Pergamon, Oxford.

Pare, C. M. B. and Jenner, G. C. (1966). Intramuscular nialamide in depressed patients. A biochemical study. Diseases of the Nervous System, 27, 193-194.

Sargant, W. (1961). Drugs in the treatment of depression. British Medical fournal, 1, 225-227. 